\title{
Global Geochemical Baselines
}

\author{
http://www.bgs.ac.uk/IUGS/
}

\section{Background}

There is worldwide concern about the potentially damaging effects of chemicals in the environment on the health of humans, animals, agriculture and ecosystems. Economic and population growth are increasing rapidly, exacerbating such problems as land degradation and pollution from uncontrolled urbanisation, industrialisation, intensive agricultural practices and over-exploitation of aquifers. These and other problems are having an impact on the geochemistry of the Earth's surface and the sustainability of its life-support systems from the local to the global scale.

Defining and understanding the current abundance and spatial distribution of chemicals in different environmental compartments (e.g. soils, sediments, surface and ground water, vegetation) are essential first steps in being able to recognise and quantify natural or human-induced changes in the future. Dr Mary Lou Zoback, former President of the Geological Society of America, stated the issue eloquently:

"Documenting and understanding natural variability is a vexing topic in almost every environmental problem: How do we recognize and understand changes in natural systems if we don't understand the range of baseline levels?" (Zoback, 2001).

Systematic geochemical mapping is the best method available to assess and provide a basis for monitoring changes in the levels of chemical elements at the Earth's surface. Geochemical maps have traditionally been valuable in addressing a whole range of environmental problems, as well as for identifying potential mineral resources at the local to national scale. Several decades of geochemical mapping by national geological surveys and related organisations throughout the world have resulted in a wealth of valuable information. However, these data cannot readily be applied to broader regional or global studies because they have been collected using different sampling, analytical and data interpretation methods (Darnley et al., 1995 - "The Blue Book"). Part of the reason behind this is that there are no internationally agreed standards for geochemical surveys.

Such incompatible data could be used if they were normalised to a reference dataset, i.e. data generated from a worldwide suite of geochemical samples collected, prepared, analysed and interpreted using a universally consistent set of protocols. Each of the available geochemical survey datasets could then be normalised to the reference dataset and interpreted across political boundaries in order to identify geochemical features, including both enrichment and depletion of elements, with the potential to affect the health of humans, animals and ecosystems. New areas with potential for undiscovered mineral resources could also be identified.

\section{History and objectives}

The Task Group on 'Global Geochemical Baselines' has the long-term goal of establishing a global geochemical database to document the concentration and distribution of chemical elements and species in the Earth's near-surface environment. The database and accompanying element distribution maps can then be used to establish a geochemical baseline against which future human-induced or natural changes to the chemistry of the land surface may be recognised and measured.

The current Task Group traces its origins to 1988 as Project 259 'International Geochemical Mapping' of UNESCO's International Geological Correlation Programme (IGCP). This first phase was concluded with the publication of UNESCO Report 19 (Darnley et al., 1995). This detailed the requirements necessary for establishing a global geochemical database through multi-media, low-density sampling on the basis of the Global Reference Network (GRN), which covers the Earth's land surface with about 5000 grid cells of $160 \times 160 \mathrm{~km}\left(\right.$ area $\left.25600 \mathrm{~km}^{2}\right)$. These requirements included:

- commonly available representative sample media, collected in a standardised manner;

- continuity of data across different landscape types;

- adequate quantities of the sample media for future reference and research requirements;

- analytical data for all elements of environmental or economic significance;

- the lowest possible detection limits for all elements; and

- strict quality control at every stage of the process.

From 1993 to 1997 , the project continued under the IGCP as Project 360: 'Global Geochemical Baselines'. The design of the GRN was finalised and sampling sites selected in a statistically random way, based on the $160 \times 160 \mathrm{~km}$ grid system. Standardised methods for geochemical sampling, sample preparation, analysis and data management to be used in conducting the global-scale geochemical survey, agreed by the representatives of more than 100 countries, were also prepared during this phase of the project. More detailed methods for sampling in semi-arid, temperate and glaciated terrains were published in a Field Manual (Salminen et al., 1998).

Following completion of the two IGCP projects, the International Union of Geological Sciences (IUGS), in collaboration with the International Association of GeoChemistry (IAGC), established the current Task Group on 'Global Geochemical Baselines'. The Task Group's main objective for this phase has been to encourage and facilitate the population of the GRN worldwide through application of the sampling, sample preparation, analytical and data management protocols established in the earlier phases of the project. This has been achieved by making the expertise within the Task Group available to countries interested in initiating a national geochemical survey.

\section{Project Organisation}

The project is led by a Steering Committee, which co-ordinates the activities of five Technical Committees and contributions made by individual country representatives. The composition of the Steering Committee is as follows:

Honorary President

Dr. Arthur Darnley (deceased), Geological Survey of Canada Canada

Co-Leaders

Dr. David Smith, US Geological Survey, USA

Prof. Jane Plant, Imperial College, UK

Scientific Secretary

Mr. Shaun Reeder, British Geological Survey, UK

Treasurer

Mr. Alecos Demetriades

IGME, Greece

The first of the Technical Committees is the Analytical Committee, chaired by Gwendy Hall of the Geological Survey of Canada. This committee is responsible for co-ordinating the work plan for the analysis of the geochemical samples, the activities of the laboratories, and the supervision of analytical quality control data.

Professor Reijo Salminen of the Geological Survey of Finland chairs both the Regional Co-ordination Committee, with responsibility for co-ordinating the project activities of contributing countries 
worldwide, and the Sampling Committee, with responsibility for supervising the development and co-ordination of sampling protocols in the various morphoclimatic environments throughout the world.

The Data Management Committee, chaired by Timo Tarvainen of the Geological Survey of Finland, is responsible for supervising sampling strategy, co-ordinating the sampling progress of the participating countries, and managing the database of sample information and analytical results.

Finally, the committee on Public Relations and Finance is chaired by Alecos Demetriades of the Institute of Geology and Mineral Exploration (IGME), Greece. This committee is active in advertising and promoting the aims, objectives and achievements of the project worldwide, including use of the World Wide Web; it also takes responsibility for raising funds for the project.

\section{Fit with IUGS Science Policy}

Current IUGS scientific policy objectives relate to global earth science issues, such as identification of mineral resources, global change, geological hazards, environmental geology and sustainable development. The work of the 'Global Geochemical Baselines' Task Group relates directly to all of these objectives through the establishment of a land-surface global geochemical reference network, providing multi-media, multi-element baseline data for a wide variety of environmental and resource applications. The project is also consistent with the strategic plan published by the IUGS Strategic Planning Committee (2000), and the International Year of Planet Earth (2005-2007) of 'Earth Sciences for Society'.

The project is closely associated with the work of the EuroGeoSurveys 'Geochemistry' Expert Group chaired by Clemens Reimann of the Geological Survey of Norway. In North America, the project has established links with the tri-national soil geochemical survey, involving the Geological Survey of Canada (GSC), the United States Geological Survey (USGS), and the Servicio Geológico Mexicano (SGM).

\section{Current Status and Achievements of the Project}

Geochemical surveys based on the GRN have been undertaken in several countries worldwide. The GRN geochemical sampling has already been completed for China (Xie and Yin, 1993; Xie and Cheng, 1997, 2001) (Figure 1) and parts of Russia. In India, the National Geophysical Research Institute (NGRI) in Hyderabad has recently completed sampling of soils and stream sediments. The samples are currently being processed at the NGRI, and will be analysed by XRF, ICP-MS and ICP-AES for major and trace elements. Geochemical maps showing the distribution for selected elements will be prepared during 2007. Higher resolution sampling based on $10 \times 10 \mathrm{~km}$ cells will begin after the lower density data has been interpreted. The US Geological Survey and the Geological Survey of Canada completed pilot studies in 2006 in preparation for a soil geochemical survey of North America. Similar studies in Mexico by the Servicio Geológico Mexicano will be completed in early 2007. Australia is carrying out an airborne gamma ray survey of the whole country as a component of the project. A considerable amount of progress has also been made in Southern Africa, Colombia, Brazil, Korea, Cyprus and many other countries. In more general terms, geological survey organisations worldwide are increasingly using the standard protocols established under this project, included also as part of their aid programmes to developing countries.

Some of the most significant multi-national progress has been achieved within Europe. As a contribution to the global project, the Western European Geological Surveys (WEGS) established a Working Group on 'Regional Geochemical Mapping', chaired initially by Professor Bjorn Bølviken, of the Geological Survey of Norway between 1986 to 1993 (Bølviken et al., 1990, 1996; Demetriades et al., 1990). Subsequently, the 'Geochemistry' Working Group continued under the Forum of European Geological Surveys (FOREGS) led by Professor Jane Plant of the British Geological Survey between 1994 and 1996 (Plant et al., 1996, 1997) and then, until 2006, by Professor Reijo Salminen of the Geological Survey of Finland. Samples from approximately 800 drainage basins, identified on the Global Reference Network within Europe, were collected using the standardised methods established by Darnley et al. (1995) and Salminen et al. (1998). A suite of geochemical samples, including stream water, stream sediment, topsoil, subsoil, floodplain sediment and humus was collected from each drainage basin by the sampling teams of 26 participating countries. Chemical analysis of the samples was completed in 2004, and data subsequently collated and examined for error by the Geological Survey of Finland. A two-volume 'Geochemical Atlas of Europe' has been published: 'Part 1: Background Information, Methodology and Maps' (Salminen et al., 2005); and 'Part 2: Interpretation of Geochemical Maps, Additional Tables, Figures, Maps and Related Publications' (De Vos et al., 2006) (Figure 2). Both volumes are available on-line from http://www.gtk.fi/publ/foregsatlas/. The complete European database of all field and geochemical data collected as part of this project, and the related digital photo archive, are also freely available at this website. The FOREGS/EuroGeoSurveys 'Geochemical Atlas of Europe' was officially launched to European Commission officers and other interested parties at the DG Environment headquarters in Brussels on the 21 September 2006.

This paper is prepared in honour of the Task Group's Honorary President, Arthur Darnley of the Geological Survey of Canada, who sadly passed away on 5 September 2006. Arthur played a pivotal role in recognising and promoting the importance of understanding geochemistry at the global scale and the need for establishing standardised data to detect geochemical effects of climate change and other
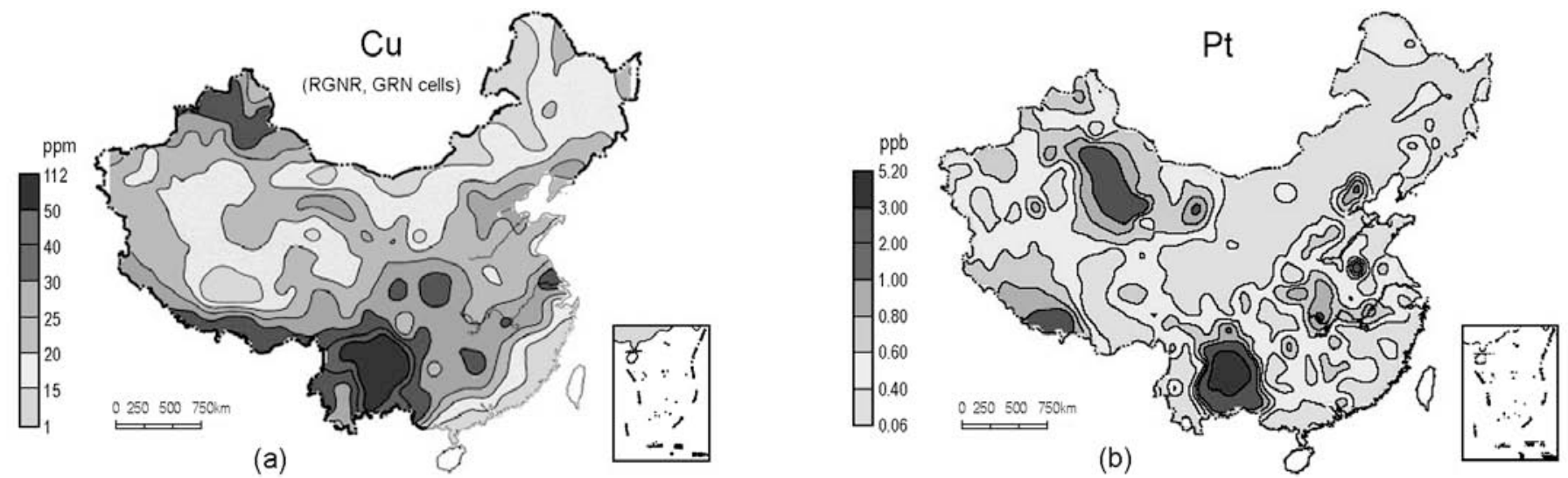

Figure 1 Geochemical distribution of (a) Cu and (b) Pt in surface floodplain sediment samples collected from GRN cells, China.

(From Xie and Cheng, 2001, Figure 3A, p. 1312 and Xueqiu, 2005, Figure 10, p. 30). 

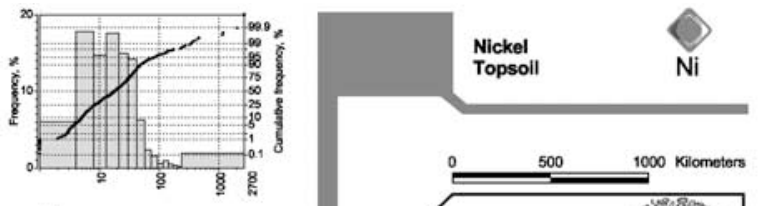

(a)

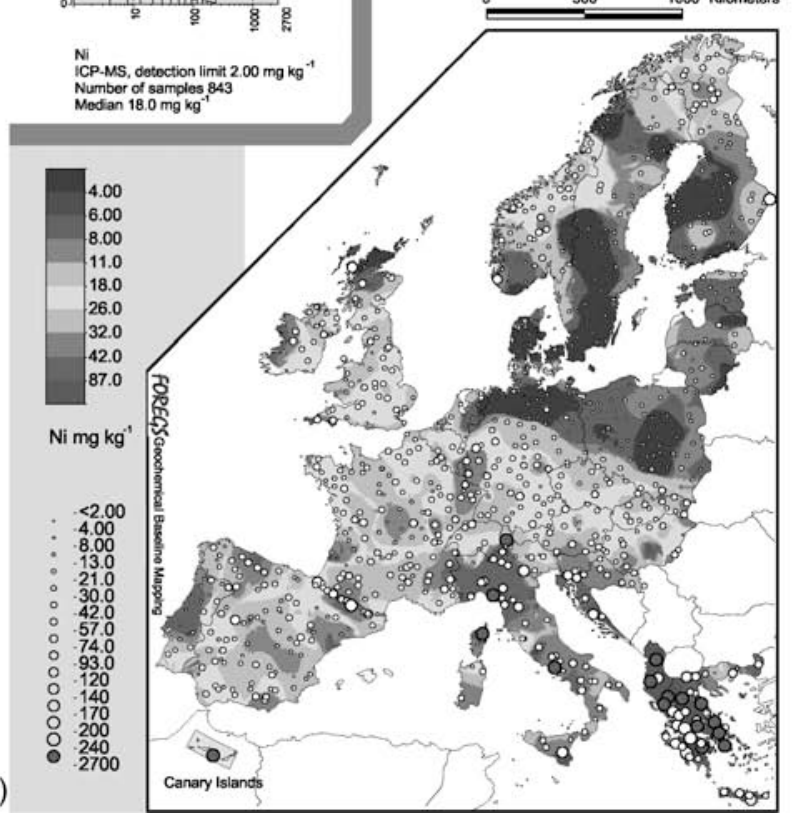

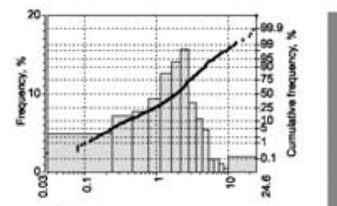

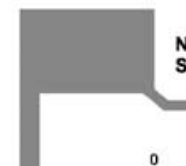

Nickel Stream water

(b)

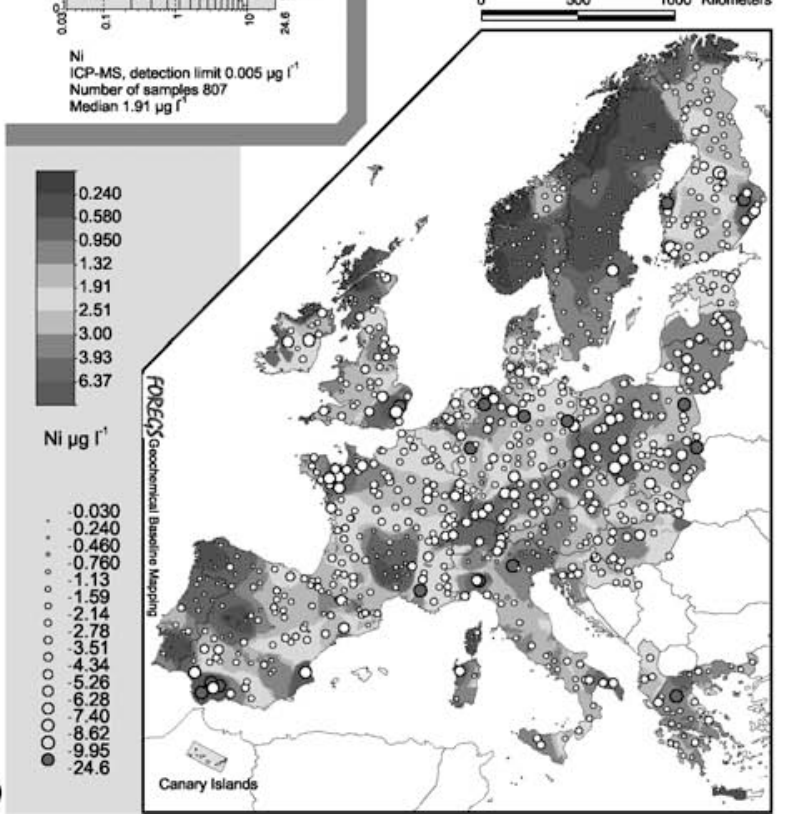

Figure 2 Nickel distribution in European (a) topsoil (b) and stream water (from Salminen et al., 2005, p.359 and 362).

natural and human influence on the planet. He was the principal architect, long-standing champion and founding chairman of the "Global Geochemical Baselines" Task Group, under the aegis of the IUGS/IAGC, and the driving force behind "The Blue Book" (Darnley et al., 1995).

The IUGS/IAGC Task Group on 'Global Geochemical Baselines' plans to run a special session dedicated to Arthur at the 2008 International Geological Congress in Oslo, Norway. The title of the session is "Geochemical Mapping from the Global to the Local Scale". The conveners will also act as guest editors for a special issue of Geochemistry: Exploration, Environment, Analysis to honour Arthur. This issue

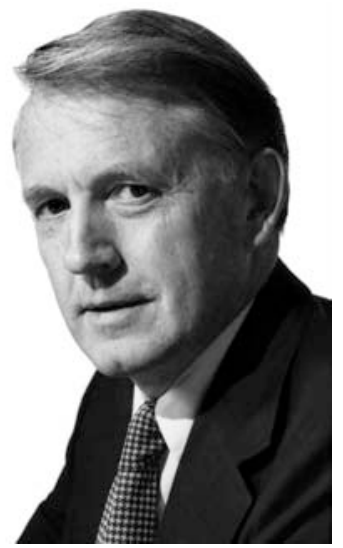

Arthur G Darnley (1930-2006) will also focus on multi-scale geochemical mapping.

\section{Contacts}

David Smith, Co-chair, dsmith@usgs.gov

Jane A Plant, Co-chair, jane.plant@imperial.ac.uk Shaun Reeder, Scientific Secretary, sre@bgs.ac.uk Alecos Demetriades, Treasurer and Chair Public Relations and

Finance Committee, ademetriades@igme.gr

Reijo Salminen, Chair Regional Co-ordination and Sampling Committees, reijo.salminen@gtk.fi

Timo Tarvainen, Chair Data Management Committee, timo.tarvainen@gtk.fi

Gwendy Hall, Chair Analytical Committee,

GHall@NRCan.gc.ca

Clemens Reimann, Chair EuroGeoSurveys Geochemistry Expert Group,Clemens.Reimann@ngu.no

\section{References}

Bøllviken, B., Bogen, J., Demetriades, A., de Vos, W., Ebbing, J., Hindel, R., Langedal, M., Locutura, J., O'Connor, P., Ottesen, R.T., Pulkkinen, E., Salminen, R., Schermann, O., Swennen, R., Van der Sluys, J. and Volden, T., 1996, Regional geochemical mapping of Western Europe towards the year 2000: Journal of Geochemical Exploration, v. 56, no. 2, pp. 141-166.

B $\notin$ lviken, B., Demetriades, A., Hindel, A., Locutura, J., O'Connor, P., Ottesen, R.T., Plant, J., Ridgway, J., Salminen, R., Salpeteur, I., Schermann, O. and Volden T., eds, 1990, Geochemical Mapping of Western Europe towards the Year 2000-Project Proposal: Western European Geological Surveys (WEGS), Geological Survey of Norway, Trondheim, NGU Report 90.106, 12 pages and 9 appendices.

Darnley, A. G., Björklund, A., B $\not l$ lviken, B., Gustavsson, N., Koval, P. V., Plant, J. A., Steenfelt, A., Tauchid, M., Xuejing, X., Garrett, R.G. and Hall, G. E. M., 1995, A global geochemical database for environmental and resource management: Final report of IGCP Project 259, Earth Sciences, 19, UNESCO Publishing, Paris, $122 \mathrm{pp}$.

Demetriades, A., Ottesen, R. T. and Locutura, J., eds, 1990, Geochemical mapping of Western Europe towards the Year 2000-Pilot Project Report: Western European Geological Surveys, Geological Survey of Norway, Trondheim, Open File Report 90-105, 9 pages and 10 appendices.

Plant, J. A., Klaver, G., Locutura, J., Salminen, R., Vrana, K. and Fordyce, F. M., 1996, Forum of European Geological Surveys (FOREGS) Geochemistry Task Group 1994-1996 Report-A contribution to the IUGS Continental Geochemical Baselines: British Geological Survey Technical Report Number WP/95/14, 52 pp.

Plant, J. A., Klaver, G., Locutura, J., Salminen, R., Vrana, K. and Fordyce, F. 1997, The Forum of European Geological Surveys Geochemistry Task Group inventory 1994-1996: Journal Geochemical Explororation, v. 59, no. 2, pp. 123-146.

Salminen, R., Tarvainen, T., Demetriades, A., Duris, M., Fordyce, F. M., Gregorauskiene, V., Kahelin, H., Kivisilla, J., Klaver, G., Klein, H., Larson, J. O., Lis, J., Locutura, J., Marsina, K., Mjartanova, H., Mouvet, C., O'Connor, P., Odor, L., Ottonello, G., Paukola, T., Plant, J.A., Reimann, C., Schermann, O., Siewers, U., Steenfelt, A., Van der Sluys, J., De Vivo, B. and Williams, L., 1998, FOREGS Geochemical mapping field manual: Geological Survey of Finland, Guide Number 47, Espoo, 42 pp. Also available at www.gtk.fi/foregs/geochem/fieldman.pdf. 
Salminen, R., chief-ed., Batista, M. J., Bidovec, M., Demetriades, A., De Vivo, B., De Vos, W., Duris, M., Gilucis, A., Gregorauskiene, V., Halamic, J., Heitzmann, P., Lima, A., Jordan, G., Klaver, G., Klein, P., Lis, J., Locutura, J., Marsina, K., Mazreku, A., O’Connor, P. J., Olsson, S., Ottesen, R. T., Petersell, V., Plant, J. A., Reeder, S., Salpeteur, I., Sandström, H., Siewers, U., Steenfeldt, A. and Tarvainen, T., 2005, FOREGS Geochemical Atlas of Europe, Part 1-Background information, methodology and maps: Geological Survey of Finland, Espoo, 525 pp. Also available at http://www.gtk.fi/publ/foregsatlas/.

De Vos, W. and Tarvainen, T., chief eds, Salminen, R., Reeder, S., De Vivo, B., Demetriades, A., Pirc, S., Batista, M. J., Marsina, K., Ottesen, R. T., O'Connor, P. J., Bidovec, M., Lima, A., Siewers, U., Smith, B., Taylor, H., Shaw, R., Salpeteur, I., Gregorauskiene, V., Halamic, J., Slaninka, I., Lax, K., Gravesen, P., Birke, M., Breward, N., Ander, E. L., Jordan, G., Duris, M., Klein, P., Locutura, J., Bel-Ian, A., Pasieczna, A., Lis, J., Mazreku, A., Gilucis, A., Heitzmann, P., Klaver, G. and Petersell, V. 2006, Geochemical Atlas of Europe. Part 2-Interpretation of Geochemical Maps, Additional Tables, Figures, Maps, and Related Publications: Geological Survey of Finland, Espoo, 690 pp. Also available at http://www.gtk.fi/publ/foregsatlas/.

Xie, X. and Yin, B., 1993, Geochemical patterns from local to global: Journal of Geochemical Exploration, v. 47, no. 1-3, pp. 109-129.

Xie, X. and Cheng, H., 1997, The suitability of floodplain sediment as a global sampling medium: evidence from China: Journal of Geochemical Exploration, v. 58, no. 1, pp. 51-62.
Xie, X. and Cheng, H., 2001, Global geochemical mapping and its implementation in the Asia-Pacific region: Applied Geochemistry, v. 16, no. 11-12, pp. 1309-1321.

Xueqiu, W., 2005, Focus on National and global scale geochemical mapping for mineral exploration and assessment in China. Explore, no. 127, pp. 23-30

Zoback, M. L., 2001, Grand Challenges in Earth and Environmental Sciences - Science, Stewardship, and Service for the Twenty-First Century: Geological Society of America Today, v. 11, no. 12, pp. 41-47.

\section{Mr Shaun Reeder}

Scientific Secretary IUGS/

IAGC Task Group on 'Global Geochemical Baselines'

British Geological Survey

Keyworth

Nottingham

NG12 $5 G G$

UNITED KINGDOM

sre@bgs.ac.uk

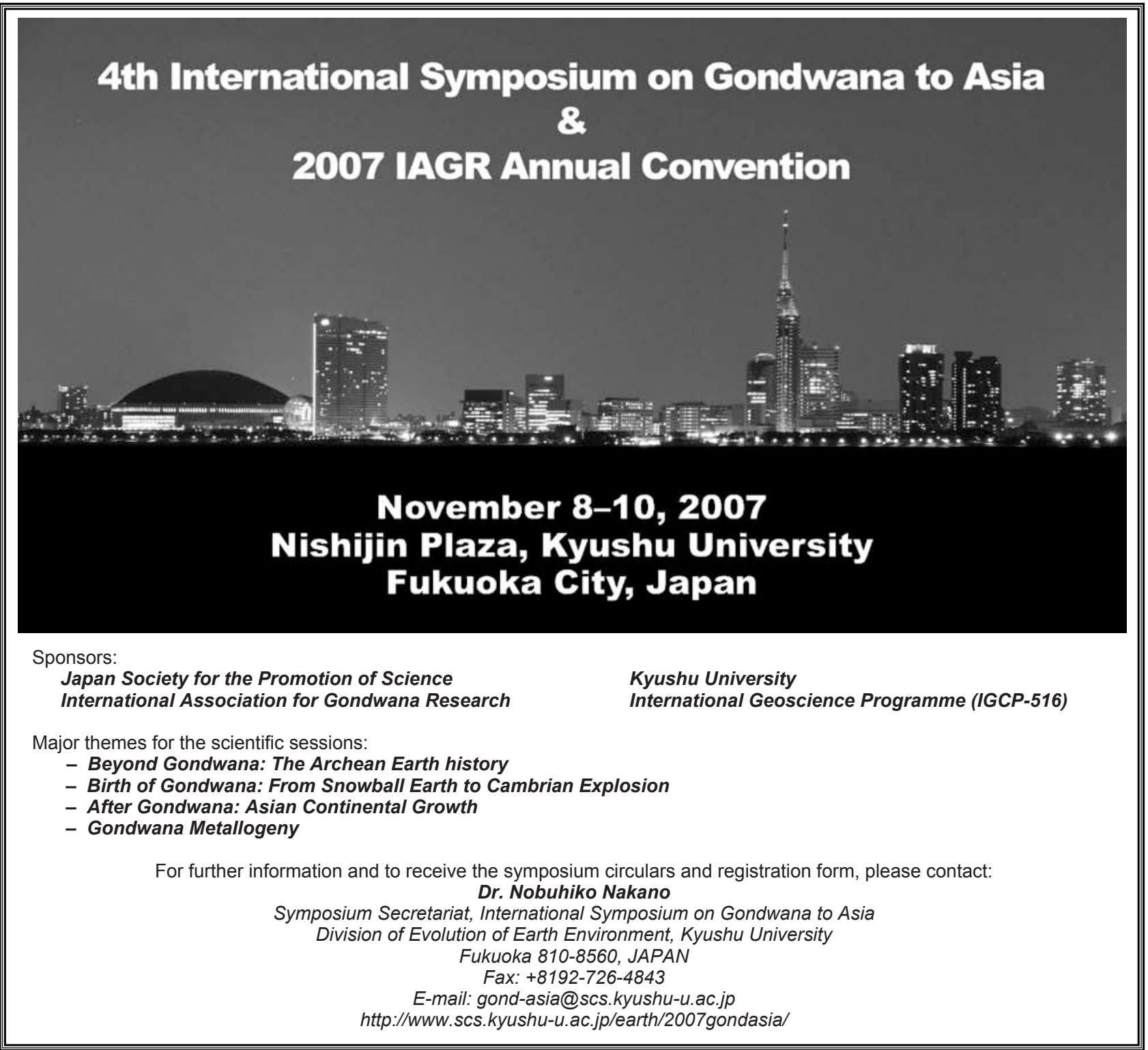

